\title{
Effect of Bank Financial Intermediation on Agricultural Performance in Nigeria
}

Ogunlokun, Ayodele Damilola*, Liasu, A. A

Department of Banking and Finance, The Federal Polytechnic, Ado, Ekiti State, Nigeria

\section{*Corresponding Author}

Ogunlokun, Ayodele Damilola

\section{Article History}

Received: 22.12 .2020

Accepted: 08.01.2021

Published: 15.01.2021

\begin{abstract}
This study examined the effect of bank financial intermediation on the performance of agricultural sector in Nigeria between 1992 and 2017. Time series data were collected from the Central Bank of Nigeria (CBN) Statistical Bulletin. Agricultural sector output (AGOUT) was proxied as the endogenous variable to measure the performance of agricultural sector, and regressed on Commercial Bank Credits to Agricultural sector (CBCA), Commercial banks' Gross Saving deposits (CGSD), Microfinance Bank Credits to Agricultural sector (MBCA), Microfinance banks' Gross Saving Deposits (MGSD) and Deposit Interest Rate (DIR) as the proxies of bank financial intermediation. Autoregressive Distributed Lag (ARDL) Model was employed for data analysis. The results showed that the previous year deviation from long-run equilibrium was corrected in the current period at an adjustment speed of $22 \%$. The result also showed that in the long run, most of the bank financial intermediation variables were positively and insignificantly stimulating agricultural performance in Nigeria. Based on these findings, it was concluded that bank financial intermediation was positive but insignificant determinant of agricultural performance in Nigeria in the long run. It was therefore, recommended that government through the Central Bank of Nigeria (CBN) should moderately increase the deposit interest rate to encourage savings while special directive should be given to banks to give priority to lending request from agricultural sector.
\end{abstract}

Keywords: Financial intermediation, Agricultural performance, Credits, Deposits, Interest rate.

JEL CODE: G21.

\section{INTRODUCTION}

Financial intermediation simply refers to the process of mobilizing idle funds by financial intermediaries from the surplus sector of the economy for productive lending to the deficit sector. The intermediaries that facilitates this fund mobilisation can either be banks or non-banks, and they can either be operating in the formal sector or informal sector. Banks as financial intermediaries are in the business of making profit from credits which they grant to borrowers from different sectors of the economy and such profit represents the difference between the interest paid to the depositiors and the interest received from the borrowers. Beginning from the early years of this country's financial market and up to the middle of 1980s, the strategies for controlling the allocation of bank credit to the productive sectors of the economy was by direct control of the structure of interest rate and the process of credit allocation. Also, it was the custom to require banks to give large chunk of their credits to growth driven sectors like agriculture, manufacturing, residential building construction, solid minerals at subsidised rate of interest, with expectation that such subsidised interest rate would translate to facilitation of growth in both investment and the overall output of the Nigerian economy.

Because of the practical problems that accompanied the direct credit control policy which include disintermediation, promotion of inefficiency in credit allocation, discouragement of financial resource mobilisation and inability to efficiently monitor the ultimate credit users of low-interest rate credits to achieve productive investment, there was transition from the direct credit control to market-based credit control policy in September 1986. This was because of the need to achieve increased efficiency in the financial resource mobilisation and utilisation in order to develop efficient management of the nation's monetary system [1].

Copyright (C) 2021 The Author(s): This is an open-access article distributed under the terms of the Creative Commons Attribution 4.0 International License (CC BY-NC 4.0) which permits unrestricted use, distribution, and reproduction in any medium for noncommercial use provided the original author and source are credited. 
As finance is the backbone of any economy, there is a connection between financial intermediation and economic growth as financial intermediaries are expected to mobilise savings, from which they grant credits to borrowers for investment in various sectors of the economy, including agricultural sector. As observed by Goldsmith [2]; Bencivenga and Smith [3], there are several ways in which financial intermediation can affect real growth of output. The first way is to raise the volume of investment and the second is to improve the volume and structure of savings. The importance of financial intermediation in providing investible capital cannot be overemphasized, and that is why Sanusi [1] opines that availability of investible capital is an important factor in the growth trajectory of any economy. Indeed, there is ample evidence to show that countries that have benefited or are benefiting from economic prosperity have been connected with an efficient mechanism for mobilising financial resources and allocating same for productive investment. Efficient financial intermediation contributes to higher levels of output, employment, and income which invariably enhances the living standards of the population.

\section{Statement of the Problem}

Certainly, there exist a good number of empirical studies on the subject matter of this study. However, most existing studies focused on the relationship between financial intermediation and the real aggregate economy as a whole rather than disaggregated economy like agricultural sector [4-8]. Therefore, it is imperative that attention is devoted to the relationship between financial intermedation and each sector of the economy, especially agricultural sector. Also, few existing studies like Udih [9], Bada [10], Nnamocha and Charles [11], Sulaiman and Aluko [12] while examining the impact of financial intermediation on economic growth, limit the scope of financial intermediation to commercial banks alone; whereas, there are other bank financial intermediaries like Micro-finance banks and merchant banks which play important role in financial intermediation process, especially to agricultural sector. The question is: what is the efect of intermediation by both commercial and microfinance banks on the perfromance of agricultural sector in Nigeria? In the light of the foregoing, this study is aimed at examining the effect of financial intermediation by both commercial and microfinance banks on the disagregated economy in Nigeria with agricultural sector in perspective. Consequently, the following hypotheses were conjectured to guide this study:

$\mathbf{H O}_{1}$ : Bank financial intermediation has no significant effect on the performance of agricultural sector in Nigeria;

$\mathbf{H 1}_{1}$ : Bank financial intermediation has significant effect on the performance of agricultural sector in Nigeria;

\section{Scope of the Study}

This study examines the effect of financial intermediation on the performance of agricultural sector in Nigeria for 26 years between the period of 1992 and 2017. The choice of this period was informed by the fact that it captures both the period during which the Nigerian financial system was fully liberated and direct credit control policy abolished as well as guided liberalisation period in Nigeria, during which banks are regulated.

\section{LITERATURE REVIEW \\ Conceptual Review \\ Financial Intermediation}

The concept of financial intermediation is not relatively new. According to Organisation of Economic Cooperation and Development (OECD) [13], financial intermediation is a productive activity in which an institutional unit incurs liabilities on its own account for the purpose of acquiring financial assets by engaging in financial transactions on the market. The role of financial intermediaries is to channel funds from lenders to borrowers by intermediating between them. For decades, financial intermediation has been a subject of study at both the macro-level, and the microlevel. At the macro-level, the significance of financial intermediation cannot be over-emphasised. However, there are mixed feelings about this. While some argue that it facilitate the efficiency of the financial system [14], others have also argued that it is passive in nature and serves as a conduit through which monetary policy is effected [15] and contracts, not available in the financial market, are implemented [16]. At micro-level, studies have shown that financial intermediation stimulates the restructuring and liquidation of distressed firms [17], as well as eliminating the inefficiencies associated with the absence of inter-temporal smoothing, as a result of incomplete market [18].

To Benigo [19], financial intermediation is the process by which financial institution accept saving from household and lend this saving to business organizations. Since high level of financial intermediation has been associated with high degree of economic development, Thus, the role of financial intermediation which facilitates the linkage between suppliers and users of financial resources is very pivotal to agricultural growth. This is because if the resources so mobilized are effectively and efficiently deployed, it will lead to an enhanced agricultural output. Hence, there should be resolute efforts to harness the enormous resource from surplus sector for increased agricultural output [20].

In his own account, Sanderson [21] defines financial intermediation as the process performed by banks by taking in funds from a depositor and then lending them out to a borrower. The banking business thrives on the financial intermediation abilities of financial institutions that allow them to lend out money at relatively high rates of interest while receiving money on deposit at relatively low rates of interest. The bank raises funds from people looking to deposit 
money, and so can afford to lend out to those individuals who need it. Looking at the various definitions of financial intermediation so far reviewed, one thing that is common is that financial intermediaiton is a process, and that such process involves three parties: the savers (surplus unit), the intermediaries (Banks and Non-banks) and the borrowers (deficit unit). Thus, the process of financial intermediation involves financial intermediaries which is an institution or individual that serves as a middleman among diverse parties in order to facilitate financial transactions. Thus, the financial intermediation process is depicted in Figure-1.

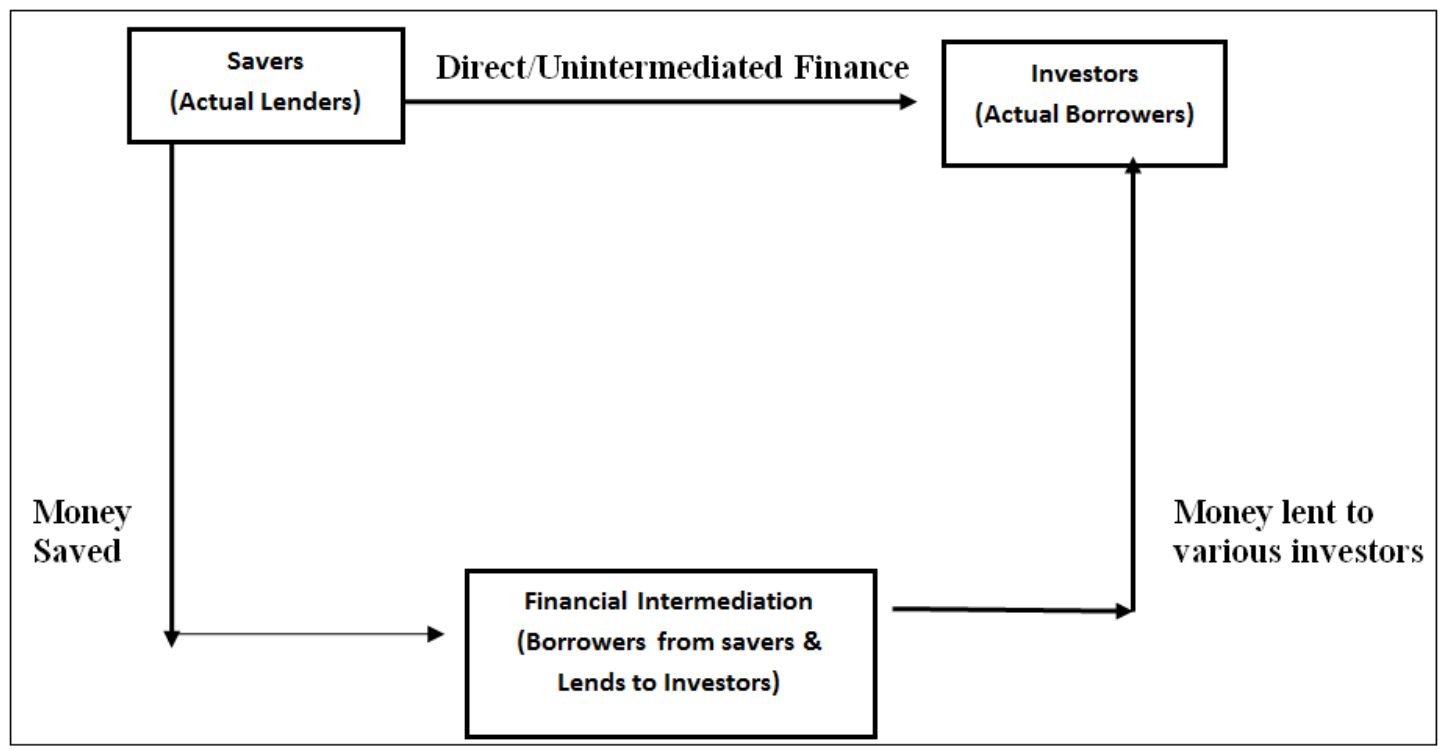

Fig-1: Financial Intermediation Flow

Source: Akinmulegun and Dare (2009) [22]

\section{OBJECTIVES, FUNCTIONS AND BENEFITS OF FINANCIAL INTERMEDIARIES Objectives}

Akinmulegun and Dare [22] posit that financial intermediation is a business opportunity and the intermediaries have ultimate private objective that teleguide and motivates their actions and reactions in the financial market. Hence, the goal of financial intermediaries include profitability, liquidity and solvency to maintain proper margin of financial safety so as to ensure that investments are sound while maintaining efficient lending portfolio.

\section{Functions}

The process of financial intermediation is a very important role in an economy like ours. The majority of economic agents are in need of resources which they cannot generate on their own while some have surplus resources. Thus, Some of the functions performed by the financial intermediaries according to Sanderson [21] are pooling the resources of small savers, mobilising wholesale finance and lines of credits, providing safekeepingand payment machanism,providing liquidity, diversifying risk, collecting and processing information as well as reconciling the conflicting preferences of lenders and borrowers among others.

\section{Benefits}

Robert and Vincenzo [23] identify some of the advantages of having financial intermediaries to include lower search cost, spreading of risk, economies of scale, matching small deposits with large loans and large deposits with small loans and market failure protection in which case the conflicting needs of lenders and borrowers are reconciled.

However, various disadvantages have also been noted in the context of climate finance and development finance institutions according to Institute for Policy Studies [24]; These include a lack of transparency, inadequate attention to social and environmental concerns, and a failure to link directly to proven developmental impacts.

\section{Types of Financial Intermediaries}

\section{Banks Financial Intermediaries (BFIs)}

The position of Sanderson [21] is that financial intermediation is the process performed by banks of taking in funds from a depositor and then lending them out to a borrower. Examples of BFIs include Commercial banks, Microfinance banks, Mercahnt bansk and Central Banks, among others. Banking business thrives on the financial intermediation abilities of financial institutions that allow them to lend out money at slightly high rates of interest while receiving money on deposit at relatively low rates of interest . 


\section{Non-bank Financial Intermediaires (NBFIs)}

Dimitri [25], in his exposition on the role of Non-bank financial intermediaries posits that Non-bank financial intermediaries complement and compete with commercial banks, forcing them to be more efficient and responsive to customers' needs. Especially, pension funds and other institutional investors that mobilize large long-term financial resources can act as countervailing forces to the dominant position of commercial banks. Non-bank financial intermediaries (NBFIs) comprise a mixed bag of institutions, ranging from cooperative societies, stock exchages, to various types of contractual savings and institutional investors (pension funds, insurance companies, and mutual funds). The common characteristic of these institutions is that they mobilize savings and facilitate the financing of different activities, but they do not accept deposits from the public. NBFIs play an important dual role in the financial system. They complement the role of commercial banks by filling gaps in their range of services. But they also compete with commercial banks and force them to be more efficient and responsive to the needs of their customers. Most NBFIs are also actively involved in the securities markets and in the mobilization and allocation of long-term financial resources. The state of development of NBFIs is usually a good indicator of the state of development of the financial system.

\section{Nexus Between Financial Intermediation and the Performance of Agricultural Sector}

According to Afangideh [26], there exists a relationship between agricultural performance and financial intermediation. For agricultural sector to grow in terms of output and productivity, it becomes paramount for the financial intermediaries to mobilise financial resources from the surplus sector for onward lending to the agricultural sector. Financial intermediairies are needed to provide the necessary funds for the agricultural sector to acquire land, mechanized farming implements, input materials and so on which invariably will lead to an increase in agricultural productivity. Financing the agricultural sector is necessary because agricultural sector has a multiplier effect on a nation's socio-economic and industrial fabric, as a strong and efficient agricultural sector would enable a country to feed its ever growing population, generate employment, earn foreign exchange and provide raw materials for industries [27]. It also has the potential to be the industrial and economic spring board, from which a country's development could takeoff, shape the landscape and provide environmental benefits. But the agricultural sector cannot do this without the needed funds.

\section{TheORETICAL FrameWORK}

\section{Joseph Schumpeter's Theory on Economic Growth and Development}

In 1911, Schumpeter propounded economic growth and development theory which was anchored on the fact that the financial intermediation role of banks is at the centre of economic growth. This theory has been used by Piabuo [28] when he examined the impact of financial sector development on economic growth between Cameroon and South Africa. Schumpeter articulately explained how financial transactions through banks take central stage in economic growth. Thus, he preferred to use development instead of term economic growth. Schumpeter suggested that bankers, through their selection and funding of entrepreneurs, promote innovative activities and spur economic growth. According to Schumpeter, the banker is an intermediary between those who has profitable business ideas to execute but lack the requisite investible funds and owners of surplus capital which is necessary to accomplish this aim. Thus, when a bank issues a loan, it authorizes the implementation of "the new profitable business ideas" for the overall benefit of the whole society (economic development). Therefore, banking activity is aimed at stimulating economic growth. Hence, the equation depicting the relationship between economic growth and financial intermediation can be expressed as:

Economic Growth $=f($ Financial Intermediation role $)$ Eq 2.1

Introducing economic growth proxy and financial intermediation proxies, equation 2.1 becomes:

RGDP $=f($ banks credits, banks' deposits, lending interest rate, deposit interest rate, etc)

Where RGDP = Real Gross Domestic Product of an economy.

\section{EMPIRICAL REVIEW}

Boyreau-Debray [29] investigated the relationship between economic growth and financial intermediation subnational level within China. The author first used evidence on the fragmentation of regional capital markets to justify the existence of local credit channels. Second, using a dataset of 26 provinces between 1990 and 1999, the study defined and introduced indicators of local banking development into the traditional growth regression framework using the GMM-system estimator. The findings indicated that the bank credit extended at the state level has a negative impact on provincial economic growth.

Ćurak, Loncar and Poposki [30] used fixed-effects panel model to explore the link between insurance industry development and economic growth in ten transition European Union member countries for the period 1992-2007. Also, they employed growth of GDP per capita as a measure of economic growth and three insurance variables (life insurance, non-life insurance, and total insurance). Furthermore, control variables were also used such as bank credit to the private 
sector, GDP per capita, stock market capitalization, Investment, Education, Openness, and Inflation. The findings of their study revealed that insurance industry development positively and significantly influences economic growth.

Chee and Nair [31] utilized Panel data with a sample of 44 Asia and Oceania countries for the period 1996 to 2005. Fixed effects generalised least squares and random effect estimator models were employed for the study. They investigated the impact of foreign direct investment (FDI) and Financial Sector Development on Economic Growth using GDP per capita, FDI to GDP ratio, financial sector development to GDP ratio and two dummy variables for least developed and developing countries as variables. They reported that development of the financial sector enhanced the contribution of Foreign Direct Investment on economic growth in the region.

Sahoo [32] used ARDL and Granger causality approach to examine the role of financial intermediation in Indian economic development from 1982-2012. The study employed variables such as real GDP, the ratio of private sector credit-to-GDP, the rate of market capitalisation-to-GDP and the sum of credit to the private sector and market capitalisation as a proportion of GDP for the analysis. The outcome of the analysis revealed that both the bank-based and market-based financial deepening have a positive impact on Indian economic growth with banking sector exalting higher influence over the financial market sector. Furthermore, unidirectional causality was found running from private sector credit to real GDP, while no causality was observed between stock market capitalization and real GDP.

Mahran [33] used time series data for Saudi Arabia from 1968 to 2010. The study employed an autoregressive distributed lag methods and the error correction model (ECM). He used broad money supply, M3 as liquid liabilities; currency plus demand and interest-bearing liabilities of banks as a percentage of GDP, credit to the private sector by commercial banks as a ratio to nominal GDP, investment to GDP ratio, government spending to GDP ratio, human development, trade openness to study Financial Intermediation and Economic Growth in Saudi Arabia. They conclude that financial intermediation has an adverse impact on the long-run real output growth in the country.

Siddiqi, Mazhar-ul-Haq and Baluch [34] reported that the flow of fund assessed by farmers was found to have increased inputs demand for the sole aim of increasing crop production. Irrigation, the elasticity of credit amount, the use of chemical pesticides and fertilizer and number of tractors etc with respect to agricultural income as the dependent variable on per cultivated as well as per cropped acre basis revealed that credit for production and tube wells has a significant and positive impact at 95 per cent level of confidence. Using VAR, the use of fertilizer and number of tractors was insignificant with positive contributions. This was due largely on the inappropriate use of tractors and fertilizer.

Ahmed and Wahid [35] investigated the financial structure and economic growth link in African countries using FMOLS and Panel cointegration technique and time series data from 1986 to 2007. The variables used in the study are per capita real GDP, rate of investment, Private credit by deposit banks and other financial institutions as a ratio of GDP, stock market capitalization, total value of listed shares as a ratio of GDP, stock market total value traded and value of total domestic shares traded as a percentage of GDP. They construct indices of financial structure and financial activity using log of the ratio of the stock market total value traded to private credit ratio and log of the ratio of stock market capitalization to private credit ratio by utilizing principle component procedure. Their result suggests that marketoriented financial system is vital in explaining output growth via enhancing efficiency and productivity. Moreover, development of banking system is significant, and it is associated with the increase of capital accumulation.

Nwite [7] carried out study on determinants of financial intermediation and its implications on economic growth in Nigeria using OLS and co-integration test. From the research findings, the study found that there was long run relationship between credit to private sector, lending rate, interest rate margin and economic growth in Nigeria. The study found that from 2004 to 2007, the period recorded the highest average annual growth rate in loan disbursement to the private sector, yet the same period recorded the worst average annual growth rate in the manufacturing capacity utilization rate. The research findings supported both theoretical and empirical evidence that financial intermediation has impacted positively on the development of Nigerian economy. The study concluded that there was significant and positive effect of financial intermediation on economic development in Nigeria.

The study of Afangideh [26] on the investigation of the several networks by which financial development is being channeled to the agricultural sector and also examines the effect of the financial sector development on the output and investment of the agricultural sector using aggregate data from 1970-2005. He adopted the Johansen cointegration and Engel-Granger two-step (EGTS) approaches. The empirical result from the study showed a significant and positive relationship between bank lending to agriculture and agricultural sector real output. The study also showed that, emphasis on investment in the agricultural sector should top the agenda of financial sector development as a primary focus on economic diversification by Nigerian governments. The lesson from this study maintained that, the performance of the Nigerian agricultural sector is enhanced by the development of the financial sector. 
Enya and Alimba [36] examined the effect of commercial bank funding on the Nigerian agricultural sector from 1986 to 2005 . The result from the OLS multiple regression result showed that, agricultural sector repayment ability, cash reserve ratio and interest rate have the theoretical signs indicating that an increase in interest rate and repayment ability of the agricultural sector causes an increase in the amount of credit by commercial banks to the agricultural sector while cash reserve ratio increases tend to decrease commercial bank funding to the Nigerian agricultural sector. This means that a per cent increase in lending and repayment ability caused a 0.0014 per cent decrease in the supply of agricultural credit while a percentage increase in cash reserve ratio will result in 0.06 per cent decrease in the supply of credit by commercial bank to the Nigerian agricultural sector during the study period.

\section{RESEARCH METHOD \\ Research Design}

Ex post facto research method was employed in this study.

\section{Sources of Data}

This study made use of data from secondary sources. Thus, annual time series data were obtained from various editions of Statistical Bulletin of the Central Bank of Nigeria and the annual reports and accounts of the commercial banks and microfinance banks between 1992 and 2017.

\section{Model Specification}

This study is modelled after the theory of economic growth as propounded in 1911 by Joseph Schumpeter. The crux of the theory is that the financial intermediation role of banks is at the centre of economic growth which comprises agricultural sector. This theory has been used in the work of Udoka and Mbat [41] when they examined the relationship between banks' credits and agricultural production in Nigeria. This study thus, adapted Udoka and Mbat [41] and specified the following model:

LnAGOUT $=\mathrm{a} 0+\mathrm{a}_{1} \operatorname{LnCBCR}+\mathrm{a}_{2} \operatorname{LnGEXPA}+\mathrm{a}_{3} \operatorname{LnACGSF}+\mathrm{a}_{4} \mathrm{INT}+\mathrm{u}$

This study adapted the above model by introducing financial intermediation component variables, and the adapted model thus became:

LnAGOUT $=f($ CGSD,MGSD, CBCA, MBCA, DIR LIR $)$

The econometric form of the adapted model is stated thus,

$\mathrm{AGOUT}=\alpha_{0}+\alpha_{1} \mathrm{CGSD}+\alpha_{2} \mathrm{MGSD}+\alpha_{3} \mathrm{CBCA}+\alpha_{4} \mathrm{MBCA}+\alpha_{5} \mathrm{DIR}+\alpha_{6} \mathrm{LIR}+\mathrm{Ut}$

Taking the natural loagrithm of the Eq (3.3) above becomes:

LnAGOUT $=\alpha_{0}+\alpha_{1}$ LnCGSD $+\alpha_{2}$ LnMGSD $+\alpha_{3}$ LnCBCA $+\alpha_{4} \operatorname{LnMBCA}+\alpha_{5}$ DIR $+\alpha_{6} \mathrm{LIR}+\mathrm{Ut}$

Where:

LnAGOUT $=$ Natural logarithm of agricultural output, proxied by Real Gross Domestic Product of agricultural sector as a measure of agricultural performance.

LnCGSD = Natural logarithm of Commercial banks' Gross Saving deposits. It is the total amount of financial resources mobilized by all commercial banks in Nigeria.

LnMGSD = Natural logarithm of Microfinance banks' Gross Saving Deposits.

LnCBCA = logarithm of Commercial Banks Credits to Agricultural sector.

LnMBCA = logarithm of Microfinance Banks Credits to Agricultural sector.

DIR = Prime deposit interest rate. This is the minimum saving deposit interest rate.

$\mathrm{LIR}=$ Prime lending interest rate. This is the minimum lending interest rate.

$\alpha 0=$ intercept of the model

$\alpha_{1}-\alpha_{6}=$ Parameters or coefficients of the exogenous variables.

\section{Apriori Expectation}

According to the theoretical framework of this study, it was expected that bank financial intermediation would have a positive effect on the perfromance of agricultural sector (Agricultural output/RGDP) in Nigeria within the years under study. Thus, it was expected that $\alpha_{1}>0 ; \alpha_{2}>0 ; \alpha_{3}>0 ; \alpha_{4} ; \alpha_{5}>0 ; \alpha_{6}<0$

\section{Method of Data Analysis}

Philips-Perron unit root test method was applied to test for stationary of the variables employed in this study. Furthermore, this study employed Autoregressive Distributed Lag Model proposed by Pesaran, Shin and Smith [40] was adopted in this study as method of analyzing the collected data. The model is advantageous as it can be applied on a time series data with different orders of integration provided the series are integrated of $I(0)$ and $I(1)$. In addition, a dynamic error correction model (ECM) can be derived from the model which makes the estimation of both the short run dynamics 
and long run equilibrium possible simultaneously after a multivariate cointegration test. Thus, the ARDL model used to examine the long run relationship takes the following forms:

$\Delta \ln$ AGOUT $_{t}=\alpha 0+\alpha_{1} \operatorname{lnAGOUT~}_{\mathrm{t}-1}+\alpha_{2} \operatorname{lnCGSD}_{\mathrm{t}-1}+\alpha_{3} \operatorname{lnMGSD}_{\mathrm{t}-1}+\alpha_{4} \operatorname{lnCBCA}_{\mathrm{t}-1}+\alpha_{5} \operatorname{lnMBCA}_{\mathrm{t}-1}+\alpha_{6} \mathrm{DIR}_{\mathrm{t}-1}+$ $\alpha_{7} \mathrm{LIR}_{\mathrm{t}-1}+\Sigma \mathrm{k}_{\mathrm{i}} \Delta \log \mathrm{AGOUT}_{\mathrm{t}-1}+\Sigma \theta_{\mathrm{i}} \Delta \log \mathrm{CBCA}_{\mathrm{t}-1}+\Sigma \gamma_{\mathrm{i}} \Delta \log \operatorname{CGSD}_{\mathrm{t}-1}+\Sigma \lambda_{\mathrm{i}} \Delta \log \mathrm{MBCA}_{\mathrm{t}-1}+\Sigma \varphi_{\mathrm{i}} \Delta \mathrm{MGSD}_{\mathrm{t}-1}+\Sigma \mu$

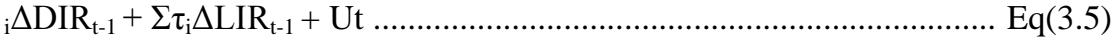

The variables are as earlier defined under variable discription. $\alpha_{2}-\alpha_{7}$ refer to the long run coefficients or multipliers while $\mathrm{k}_{\mathrm{i}}, \pi_{\mathrm{i}}, \theta_{\mathrm{i}}, \gamma_{\mathrm{i}}, \lambda_{\mathrm{i}}, \varphi_{\mathrm{i}}, \mu_{\mathrm{i}}, \tau_{\mathrm{i}}$ are the short run coefficients or multipliers.

Lastly, we conducted Bounds test in order to statistically detect the presence of cointegration; and in the final stage, we estimated the short run dynamic parameters by estimating unrestricted error correction model (ECM) associated with the long run estimates using the following equation:

$\Delta \ln$ AGOUT $_{\mathrm{t}}=\alpha 0+\alpha_{1} \operatorname{lnAGOUT}_{\mathrm{t}-1}+\alpha_{2} \operatorname{lnCGSD}_{\mathrm{t}-1}+\alpha_{3} \operatorname{lnMGSD}_{\mathrm{t}-1}+\alpha_{4} \operatorname{lnCBCA}_{\mathrm{t}-1}+\alpha_{5} \operatorname{lnMBCA}_{\mathrm{t}-1}+\alpha_{6} \mathrm{DIR}_{\mathrm{t}-1}+$

$\alpha_{7} \mathrm{LIR}_{\mathrm{t}-1}+\Sigma \mathrm{k}_{\mathrm{i}} \Delta \log \mathrm{AGOUT}_{\mathrm{t}-1}+\Sigma \theta_{\mathrm{i}} \Delta \log \mathrm{CBCA}_{\mathrm{t}-1}+\Sigma \gamma_{\mathrm{i}} \Delta \log \mathrm{CGSD}_{\mathrm{t}-1}+\Sigma \lambda_{\mathrm{i}} \Delta \log \mathrm{MBCA}_{\mathrm{t}-1}+\Sigma \varphi_{\mathrm{i}} \Delta \mathrm{MGSD}_{\mathrm{t}-1}+\Sigma \mu$ ${ }_{\mathrm{i}} \Delta \mathrm{DIR}_{\mathrm{t}-1}+\Sigma \tau_{\mathrm{i}} \Delta \mathrm{LIR}_{\mathrm{t}-1}+\Psi \mathrm{ECM}_{\mathrm{t}-1}+\mathrm{Ut}$ $\mathrm{Eq}(3.5)$

Where $\Psi \mathrm{ECM}_{\mathrm{t}-1}$ is the coefficient that measure the speed of adjustment or convergence of $\Delta \ln A G O U T$ to the equilibrium in case there is deviation; which must be negative and statistically significant to be regarded as rightly signed $[5,10]$.

\section{Results, Discussions AND FindingS}

\section{Unit Root Test}

The Philip Perron Unit root test procedure examined the optimal lag length using Schwarz Information Criteria (SIC), before proceeding to identify the probable order of stationarity. The results of the tests for all the variables and for the models with intercept are presented in Table-1. First for their logarithmic levels, and then (in cases where it was found that the series contain a unit root) for their first differences.

Table-1: Philips Perron Unit Root Test Results Unit root test at logarithmic levels $\mathrm{H} 0: \mathrm{b}=0 ; \mathrm{Ha}: \mathrm{b}>0$

\begin{tabular}{|c|c|c|c|c|c|}
\hline Variables & $\begin{array}{l}\text { Critical value } \\
@ 1 \%\end{array}$ & $\begin{array}{l}\text { Critical value } \\
@ \mathbf{5 \%}\end{array}$ & $\begin{array}{l}\text { Philips Perron test } \\
\text { statistics }\end{array}$ & Remarks & $\begin{array}{l}\text { Order of } \\
\text { Integration }\end{array}$ \\
\hline LAGOUT & -3.724070 & -2.986225 & 0.508123 & $\begin{array}{l}\text { Non- } \\
\text { stationary }\end{array}$ & Nil \\
\hline LCBCA & -3.724070 & -2.986225 & -1.347320 & $\begin{array}{l}\text { Non- } \\
\text { stationary }\end{array}$ & Nil \\
\hline LCGSD & -3.724070 & -2.986225 & -1.650364 & $\begin{array}{l}\text { Non- } \\
\text { stationary }\end{array}$ & Nil \\
\hline LMBCA & -3.724070 & -2.986225 & -2.140678 & $\begin{array}{l}\text { Non- } \\
\text { stationary }\end{array}$ & Nil \\
\hline LMGSD & -3.724070 & -2.986225 & -1.752094 & $\begin{array}{l}\text { Non- } \\
\text { stationary }\end{array}$ & Nil \\
\hline DIR & -3.724070 & -2.986225 & $-3.248108 *$ & Stationary & $\mathrm{I}(0)$ \\
\hline LIR & -3.724070 & -2.986225 & $-5.805317^{*}$ & Stationary & $\mathrm{I}(0)$ \\
\hline & & \multicolumn{4}{|c|}{ Unit root test at first differences } \\
\hline Variables & Critical value@1\% & Critical value@5\% & Philips Perron test statistics & & $\begin{array}{l}\text { Order of } \\
\text { Integration }\end{array}$ \\
\hline AGOUT & -3.737853 & -2.991878 & -4.678953 & Stationary & $\mathrm{I}(1)$ \\
\hline LCBCA & -3.737853 & -2.991878 & -6.594028 & Stationary & $\mathrm{I}(1)$ \\
\hline LCGSD & -3.737853 & -2.991878 & -3.684742 & Stationary & $\mathrm{I}(1)$ \\
\hline LMBCA & -3.737853 & -2.991878 & -9.445244 & Stationary & $\mathrm{I}(1)$ \\
\hline LMGSD & -3.737853 & -2.991878 & -8.602574 & Stationary & $\mathrm{I}(\mathrm{I})$ \\
\hline DIR & -3.737853 & -2.991878 & -4.729335 & - & $\mathrm{I}(0)$ \\
\hline LIR & -3.737853 & -2.991878 & -20.99146 & - & $\mathrm{I}(0)$ \\
\hline
\end{tabular}

Notes: *Denotes significance at the $5 \%$ level and the rejection of the null hypothesis of non-stationarity.

Source: Author's Computation (2019)

The stationary results in Table-3, indicated that majority of the series was non-stationary when the variables were defined in levels with the exception of DIR and LIR which are stationary at levels . However, first differencing the series removes the non-stationary components the remaining variables and the null hypotheses of non-stationarity were 
robustly and clearly rejected at both $1 \%$ and $5 \%$ significance levels, suggesting that the variables of interest were integrated of diffrent orders, i.e order one $\mathrm{I}(0)$ and $\mathrm{I}(\mathrm{I})$, which is the major condition for employing ARDL model method of analysis.

\section{ARDL Model Dynamic Stability Test}

The dynamic stability of the ARDL model was tested by estimating the inverse root of AR characteristic polynomial. The result as depicted on Figure-2 shows that all the roots were inside the unit circle which implied that the model of this study was dynamically stable.

\section{Inverse Roots of AR Characteristic Polynomial}

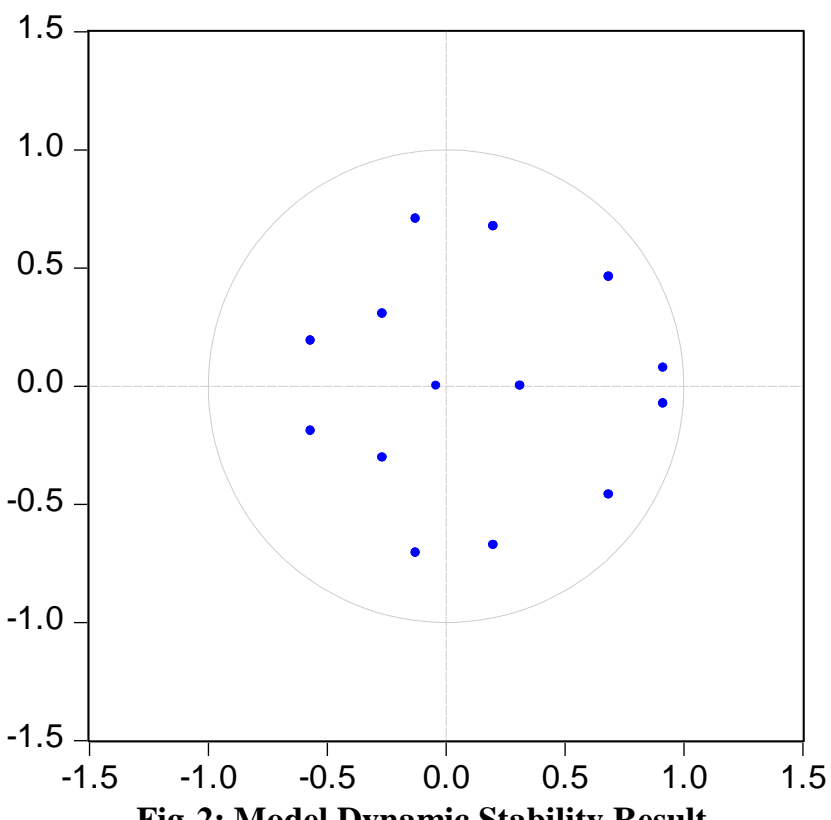

\section{Cointegration Bound Test}

The F-statistic value of 9.90 is evidently above the lower $\mathrm{I}(0)$ and upper $\mathrm{I}(1)$ critical values bound. This indicated that there was no enough reason to accept the null hypothesis that there was no existence of long-run equilibrating relationship among the variables of interest. It was therefore, concluded that there was existence of cointegrating equilibrium relationship among the variables.

Table-2: Co-integration Bound Test Result

\begin{tabular}{|c|c|c|}
\hline \multicolumn{3}{|c|}{ ARDL bounds Test } \\
\hline \multicolumn{3}{|c|}{ Date: 05/14/19 Time: $12: 11$} \\
\hline \multicolumn{3}{|c|}{ Sample: 19942017} \\
\hline \multicolumn{3}{|c|}{ Included observations: 24} \\
\hline \multicolumn{3}{|c|}{ Null Hypothesis: No long-run relationships exist } \\
\hline Test Statistic & Value & $\mathrm{k}$ \\
\hline F-statistic & 9.909754 & 6 \\
\hline \multicolumn{3}{|c|}{ Critical Value Bounds } \\
\hline Significance & I0 Bound & I1 Bound \\
\hline $10 \%$ & 2.12 & 3.23 \\
\hline $5 \%$ & 2.45 & 3.61 \\
\hline $2.5 \%$ & 2.75 & 3.99 \\
\hline $1 \%$ & 3.15 & 4.43 \\
\hline
\end{tabular}

\section{Error Correction Model (ECM)}

Having established the existence of long-run cointegrating relation among the variables in the model, we proceeded to estimate the error correction model of equation (3.5), with a view to capturing the short-run dynamics of the model such as the speed of adjustment to equilibrium or convergence in the case of any shock. The result of the foregoing was displayed in Table-3. 
Table-3: Error Correction Model (ECM) and Long Run Coeffcients with ARDL

\begin{tabular}{|l|l|l|l|l|}
\hline \multicolumn{5}{|l}{ Long Run Coefficients } \\
\hline Variable & Coefficient & Std. Error & t-Statistic & Prob. \\
\hline LCBCA & 0.208541 & 0.157543 & 1.323708 & 0.2272 \\
\hline LCGSD & 0.165406 & 0.335039 & 0.493693 & 0.6366 \\
\hline LMBCA & -0.184641 & 0.171488 & -1.076700 & 0.3173 \\
\hline LMGSD & 0.252747 & 0.255468 & 0.989346 & 0.3555 \\
\hline DIR & -0.078009 & 0.061625 & -1.265871 & 0.2461 \\
\hline LIR & 0.229106 & 0.213370 & 1.073750 & 0.3185 \\
\hline ECM(-1) & -0.219003 & 0.229092 & -0.955961 & 0.3709 \\
\hline C & 2.317386 & 2.824771 & 0.820380 & 0.4390 \\
\hline
\end{tabular}

Source: Authur's computation (2019)

Table- 3 contains the short-run coefficients of the Error Correction estimates. The Error Correction Term (ECT), which represents the speed of adjustment or convergence to long-run equilibrium is -0.22 . The coefficient was rightly signed which connoted that the previous year deviation from long-run equilibrium was corrected in the current period at an adjustment speed of $22 \%$. This meant that when the agricultural output was at disequilibrium level due to experience of any shock by the explanatory variables, the speed of its adjustment to converge to equilibrium was $22 \%$.

Looking at Table-3, it is obvious that four of the exogenous variables (CBCA, CGSD, MGSD and LIR) have long-run positive and insignificant relationship with endogenous variables while the remaining two exogenous variables (MBCA and DIR) maintains insignificant long-run negative relationship. In this case, commercial banks' credits to agriculture (CBCA), gross saving deposit of the commercial banks (CGSD) and gross saving deposit of the microfinance banks (MGSD) and lending interest rate all have positive co-integrating relationships with the performance of agriculture (AGOUT) in the long-run. On the other hand, both micro-finance banks' credits to agriculture (MBCA) as well as the saving interest rate (DIR) have negative long-run relationship with agricultural performance.

Therefore, in the long-run, $1 \%$ increase or decrease in the CBCA was associated with about $21 \%$ increase or decrease in the average mean value of agricultural output. This relationship conforms to theoretical expectation because increase in banks' credit to agricultural sector is expected to reflect in terms of increase in the output of the sector. This finding suggests that commercial banks' credits are beneficial to Agricultural performance and plays much of an important role in the growth process of the sector. This may be because the commercial banks' credit policy has given priority to lending significant portion of their deposits to agricultural sector. Also, $1 \%$ increase in CGSD culminates in about $16.5 \%$ increase in the average value of agricultural output and vice versa. This is in conformity with theoretical expectation and underscores the ability of the commercial banks to quickly transform the significant portion of their gross deposits into credits for onward lending to finance agricultural investments.

Furthermore, the average value of agricultural output increases or decreases by about $18.5 \%$ if MBCA falls or rises by $1 \%$. Therefore, in the long-run, microfinance banks credit is a negative and insignificant determinant of agricultural performance against theoretical expectation. With respect to MGSD, average value of agricultural output tends to increase by about $25 \%$ in the event of $1 \%$ increase in MGSD and vice versa. MGSD thus conforms to apriori expectation of increasing agricultural performance due to increasing saving deposits with microfinance banks; this is notwithstanding of the fact that percentage of credits to agriculture in relation to microfinance aggregate deposits base in the last 10 years has been swinging between $0.1 \%$ and $0.9 \%$ as revealed by CBN statistical bulletin [37]. In case of deposit interest rate, $1 \%$ rise or fall in the level of DIR caused the average value of agricultural output to decrease or increase by about $7.8 \%$. This result also failed to affirm the theoretical expectation that increase in deposit interest rate will provoke aggressive deposit from the surplus sector because every rational investor aspires to earn high return on their investment. The reason for inverse relationship may not be far from the too low or insignificant deposit interest rate that is currently in operations in the Nigerian banking sector which does not encourage rational investors to bring deposits into the banking sector due to low expected returns on such deposit. Increase in deposit base of the banks is expected to increase their ability to lend more to agricultural sector, and increase in lending to agricultural sector is expected to have multiplier effect of improving the performance of the sector.

Lending interest rate also defied expected relationship as it showed positive relationship in the long run instead of negative relationship. Meanwhile, a closer look at the t-statistics revealed that all the exogenous variables were statistically insignificant to the estimated co-integrating and long-run model as their t-statistics were less than 2. Standard errors in the square parentheses were the standard deviations of the sampling distribution of the estimator which measures the precision of the estimates in the long-run co-integrating model. In this case, the standard errors of the estimated coefficients of the exogenous variables were relatively low as expected, 


\section{Residuals Diagnostic Test \\ Autocorrelation Test}

To test whether the residuals from the estimated model were free from autocorrelation or were serially uncorrelated, Breusch-Godfrey serial correlation test was conducted and the results were depicted on the Table- 4 .

Table-4: LM serial Correlation Test

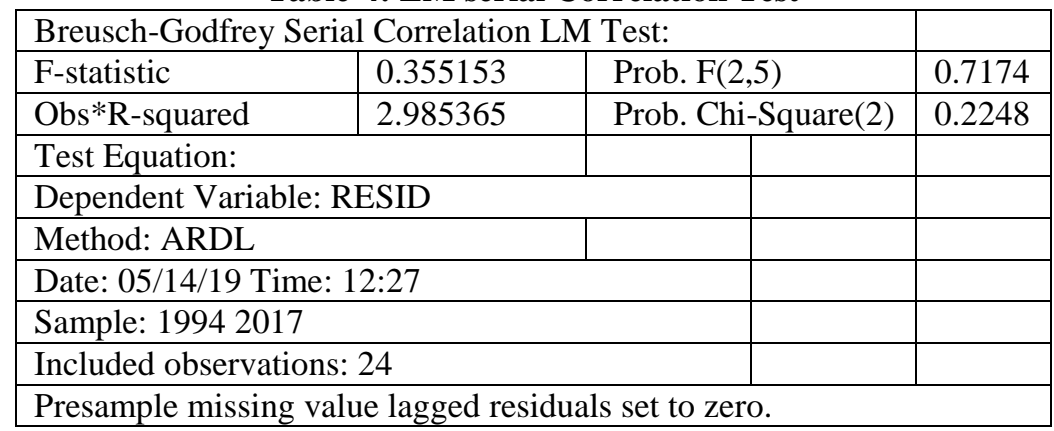

Source: Author's computation (2019)

The null hypothesis (H0) for this test is that the residuals were serially uncorrelated. From the Table-4, the Fstatistic p-value of 0.7174 was actually more than 0.01 and 0.05 ; it implied that the null hypothesis was accepted at both $1 \%$ and $5 \%$ significance levels. Hence, it was concluded that the residuals were serially uncorrelated and the residuals were free from bias.

\section{Homoskedasticity Test}

In a bit to test the efficiency of the estimator used in this study, the Breusch-Pagan-Godfrey homoskedasticity test was conducted on the residuals of the ARDL estimates. The results were depicted on Table-5:

Table-5: Heteroskedasticity Test: Breusch-Pagan-Godfrey

\begin{tabular}{|l|l|l|l|}
\hline Heteroskedasticity Test: Breusch-Pagan-Godfrey \\
\hline F-statistic & 0.355695 & Prob. F(16,7) & 0.9588 \\
\hline Obs*R-squared & 10.76240 & Prob. Chi-Square(16) & 0.8239 \\
\hline Scaled explained SS & 0.947159 & Prob. Chi-Square(16) & 1.0000 \\
\hline
\end{tabular}

Source: Author's Computation (2019)

Also, the null hypothesis is for this test is that the residuals are homoskedastic, and from the Table 4.5, the Fstatistic p-value of 0.9588 is greater than critical values of 0.01 and 0.05 , it showed that null hypothesis was accepted at both $1 \%$ and $5 \%$ significance levels. It was therefore, concluded that the residuals were homoskedastic and the estimation was efficient..

\section{Test of Hypotheses and Discussions of Findings}

This sub-section conducted test of hypothesis to validate or invalidate the earlier formulated hypotheses by using the p-value test of significance. The decision rule was guiding the testing process is that if the calculated p-value is less than the critical value at 5\% significance levels, the alternative hypothesis (H1) of the study is accepted while the null hypothesis (H0) is rejected and vice versa.

$\mathbf{H 0}_{1}$ : Bank financial intermediation has no significant effect on the performance of agricultural sector in Nigeria;

$\mathbf{H 1}_{1}$ : Bank financial intermediation has significant effect on the performance of agricultural sector in Nigeria;

From the results obtained on Table-3, the p-values calculated for all the proxies of banks financial intermediation were greater at $5 \%$ significance levels than the 0.05 critical value. Hence, the alternative hypothesis was rejected while the null was accepted. The implication of this was that bank financial intermediation had no significant effect on the performance of agricultural sector in Nigeria during the period under study.

Despite the insignificant relationship found out by this study between bank financial intermediation and agricultural perfromance, this study found evidence that bank financial intermediation and agricultural performance moved together in the long run which aligns with the findings of Shittu [6], Nwite [7], Tonye and Adabai [5], while the only deviation was that rather than aggregate economy, this study focused on disaggregated sector. The estimated model results revealed that in the long run, a positive but insignificant relationship existed between commercial banks' credits to agriculture and the performance of agricultural sector. This confirms the theoretical assertion of Joseph Schumpeter theory of economic growth, and expectation that an increase in credit to the agriculture sector by the financial intermediaries provides investible funds needed by farmers for investment in agriculture in the country. This in turn leads 
to an increase in the output of agriculture. This finding is in line with the finding of the study conducted by Afangideh [26] when he found a positive (although significant) relationship between bank lending to agriculture and agricultural sector real output. This finding however, contradicts the finding of Obilor [38] who concluded in his study that commercial banks' credit to agricultural sector for the period 1984 to 2007 has significant negative impact on agricultural productivity in Nigeria. Furthermore, This study found a positive but insignificant relationship among the gross saving deposits of both commercial banks and microfinance banks and the performance of agriculture in Nigeria both in the short-run and long run. Apparently, this conforms to the theoretical expectation that increase in the deposit base of banks should ordinarily translates to more loanable funds for the banks to extend more credit facilities to farmers. Also, the reason for this insignificant relationship of saving deposits with agricultural output might be because during the period under study, according to CBN statistical bulletin 2017, the highest percentage of lending by commercial banks to Agriculture in relation to their aggregate deposit is $20 \%$ in 1996 and this has declined over the years to lowest value of $1.4 \%$ in 2008 . As at 2017, the total lending of commercial banks to agriculture was $3.2 \%$.

\section{CONCLUSION AND RECOMMENDATIONS CONCLUSION}

This study re-affirms the fact that one of the most important functions of banks and other financial intermediaries is to mobilize deposits in order to make credit available to the investors at affordable rate, most especially to the agricultural sector. This is because low credit or high lending rate will amount to low level of investment which transmits to low agricultural output. Also, low deposit interest rate will translate to lackluster on the part of the surplus sector that would prefer to invest their money in where they can earn higher returns to depositing their surpluses with banks. Agricultural credit is believed to be a very important ingredient in farming activities as adequate provision of funds to farmers makes all activities in the farm possible and leads to increase in output. Thus, having empirically examined the effect of bank financial intermediation on agricultural performance in Nigeria, and in line with the findings of this study, it was therefore, concluded that bank financial intermediation was a positive but not a significant determinant of agricultural performance in the long-run. This is because in the long run, most of the bank financial intermediation variables were positively and but insignificantly stimulating agricultural performance in Nigeria. This conclusion corroborates those of the studies of Afangideh [26], Shittu [6], Kolawole [39], Nwite [7], Tonye and Adabai $[5]$.

\section{RECOMMENDATIONS}

Based on the findings of this study, the following recommendations were made:

i. The positive effect of commercial banks' credit on agricultural performance calls for policy which can promote more allocation of credit to the agricultural sector in Nigeria. This can be achieved by the Central Bank of Nigeria $(\mathrm{CBN})$ lowering the lending interest rate charged on farmers for money borrowed for the purpose of agricultural production as well as giving special directive to prioritize lending to agricultural sector.

ii. Commercial banks' deposits and microfinance banks deposits had positive but insignificant relationship with agricultural performance; hence, monetary authority should wade in and encourage commercial banks to engage in aggressive deposit mobilization and lending larger part of their deposits to agricultural sector so as to increase the agricultural output.

iii. Since micro-finance banks' credits were found to be negatively related to agricultural performance, government through Central Bank of Nigeria should consider policies which include bailing out ailing micro-finance banks in the same manner in which ailing commercial banks usually bailed out; enforcement of good corporate governance as well as proper credit monitoring. All these will reduce the increasing number of micro-finance banks that close down on daily basis, and reposition the banks to make more credit available to the agricultural sector and reverse the trends of negative relationship with the sector.

iv. Since deposit interest rate had negative effect on agricultural performance, there is urgent need for policy to review and constantly monitor the deposit interest rate payable by commercial banks to depositors which is presently not encouraging to boost inflows of deposit which must have accounted for the reason for negative relationship; this will encourage depositors or surplus sector to deposit more of their surplus funds with the banks, and as a result of this, there will be increase in the lending capacity of the banks as more deposits are available for lending to stimulate agricultural performance.

\section{REFERENCES}

1. Sanusi, J. O. (2002). Importance of financial intermediation in sustaining economic growth and development: the banking sector review. A keynote address delivered at the banking seminar, organised by the Institute of Directors, June 13, 2002.

2. Goldsmith, R. (1969). Financial structure and development. The Economic Journal, 80(318), 365-367.

3. Benchivenga, V., Smith, B., \& Starr, R. (1995). Transactions costs, technological choice, and endogeneous growth. Economic Theory, 67, 153-177. 
4. Allen, S. D., \& Ndikumana, L. (1998). Financial intermediation and economic growth in Southern Africa. Working Paper Series of Research Division, Federal Reserve Bank of St. Louis. Retrieved from www.gatewayarch.com.

5. Tonye, O., \& Andabai, P. W. (2014). Financial intermediation and economic growth in nigeria, 1988 - 2013: A Vector Error Correction Investigation. Mediterranean Journal of Social Sciences. 5(17), 20-24.

6. Shittu, A. I. (2012). Financial intermediation and economic growth in Nigeria. British Journal of Arts and Social Sciences, 4(2), 164-179.

7. Nwite, S. C. (2014). Determinants of financial intermediation and its implications on economic growth in Nigeria. British Journal of Marketing Studies, 3(9), 49-56.

8. Yusifzada, L., \& Mammadova, W. D (2015). Financial intermediation and economic growth.working paper number 1091 April 2015.

9. Udih, M. (2014). Bank credits and agricultural development: does it promote entrepreneurship performance? International Journal of Business and Social Science, 11(1); 102 -104.

10. Bada, O. T. (2017). The effect of banks' credits on the development of manufacturing and agricultural sectors of Nigeria's economy. International Journal of Advanced Studies in Economics and Public Sector Management, 5(1), $119-122$

11. Nnamocha, P. N., \& Charles, N. E. (2015). Bank credit and agricultural output in Nigeria (1970 - 2013): An Error Correction Model (ECM) Approach. British Journal of Economics, Management \& Trade, 10(2), 1-12.

12. Sulaiman, S., Adedamola, L., Aluko, A., \& Adewale, O. (2015). Financial intermediation and economic growth: a test for causality in Nigeria. Banks \& bank systems, (10, Iss. 4), 69-74.

13. Organisation of Economic Cooperation and Development (2001). Towards the economic survival of developing countries; kings Press Ltd.

14. Gromb, D., \& Vayanos, D. (2010). A model of financial capital liquidity based on intermediary capital. Journal of European Economic Association, 8(23), 456-466.

15. Benston. G., \& Smith, J. (1975). A transaction cost approach to the theory of financial intermediation. Journal of Finance, 31(2), 215-231.

16. Holmström, B., \& Tirole, J. (1998). Private and public supply of liquidity. Journal of political Economy, 106(1), 140.

17. Araujo, L., \& Minetti, R. (2007). Financial intermediaries as markets for firms' assets, historical simulation approach. Journal of Economic and Monetary, 117, 1380- 1402. Integration. 9(1), 75-97.

18. Allen, F., \& Gale, D. (1997). Financial markets, intermediaries, and intertemporal smoothing. Journal of political Economy, 105(3), 523-546.

19. Benigo. (1987). Banking principles and Practice. Lagos: B.Print Publishing Ltd.

20. Igyo, A. J., Simon, J., \& Jane, E. M. (2016). Financial intermediation and agricultural output in Nigeria: An impact analysis of deposit money banks' credit. International Journal of Agricultural Economics, 1(1), 16-25.

21. Sanderson, A. (2014). Importance of financial intermediation. Retrieved from https://www.herald.co.zw/importance-of-financial-intermediation/.

22. Akinmulegun, S. O., \& Dare, F. D. (2009). Introduction to Finance. Ado Ekiti: Godliness Press and Publisher.

23. Robert E. W., \& Vincenzo, Q. (2012). Money and Banking: Ontario: Harvard University Press.

24. Institute for Policy Studies. (2013). Financial Intermediaries. A Glossary of Climate Finance Terms, Washinton: IPS.

25. Dimitri, V. (1998). Role of non-bank financial institutions. Retrieved from https://elibrary.worldbank.org/doi/abs/10.1596/1813-9450-1892.

26. Afangideh, U. J (2006). Financial development and agricultural investment in Nigeria: Journal Finance and Accounting, 4(1), 1-10.

27. Ogen, O. (2004). Agriculture and economic development in Malaysia, 1960-1995: A Viable Model for Nigeria. Journal Economic and Financial Studies, 1(1).

28. Piabuo, S. M., Baye, F. M., \& Tieguhong, J. (2015). Effects of credit constraints on the productivity of small and medium-sized enterprises in Cameroon.

29. Boyreau-Debray, R.U. (2003). Financial Intermediation and Economic growth: New evidence from Asia and Oceania. International Journal of Economics and Finance, 2(2), 107-112.

30. Ćurak, M., Lončar, S., \& Poposki, K. (2009). Insurance sector development and economic growth in transition countries. International Research Journal of Finance and Economics, 34(3), 29-41.

31. Chee, Y. L., \& Nair, M. (2010). The impact of FDI and financial sector development on economic growth: Empirical evidence from Asia and Oceania, International Journal of Economics and Finance. 2(2), 107.

32. Sahoo, S. (2014). Financial intermediation and growth: bank-based versus market-based systems margin: The Journal of Applied Economic Research, 8(2), 93-114.

33. Mahran, H. A. (2012). Financial intermediation and economic growth in saudi arabia: An empirical analysis, $1968-$ 2010. Modern Economy Journal, 3(05), 626.

34. Siddiqi, M. W., Mazhar-ul, H., \& Baluch, K. N. (2004). Institutional credit: a policy tool for enhancement of agricultural income of Pakistan. International Research Journal of Arts \& Humanities, 37,158-174. 
35. Ahmed, A. D., \& Wahid, A. N. (2011). Financial structure and economic growth link in African countries: a panel cointegration analysis. Journal of Economic Studies, 38(3), 331-357.

36. Enya, V. \& Alimba, J. (2008). Analysis of factors affecting the supply of commercial banks credit to the agricultural sector In Nigeria. Continental Journal of Agricultural Economics, 2, 74-77.

37. Central Bank of Nigeria (2016). Annual Statistical Bulletin. Abuja, Nigeria: Author from panel data. The Quarterly Review of economics and finance, 51(1), 88-104.

38. Obilor, S. I. (2013). The impact of commercial banks' credit to agriculture on agricultural development in Nigeria: An econometric analysis. International Journal of Business, Humanities and Technology, 3(1), 85-94.

39. Kolawole, F. (2013). Effect of interest rate and some macroeconomic variables on the performance of the nigerian agricultural sector. Nigerian Journal of economic and Financial Review, 3(2):37-45.

40. Pesaran, M. H., Shin, Y., \& Smith, R. J. (2001). Bounds Testing Approaches to the Analysis of Level Relationships. Journal of Applied Econometrics, 16(3):289-326.

41. Udoka, C. O., Mbat, D. O., \& Stephen, B. D. (2016). The effect of commercial banks' credit on agricultural production in Nigeria. Journal of Finance and Accounting, 4(1):1-10.

Citation: Ayodele Damilola \& Liasu (2021). Effect of Bank Financial Intermediation on Agricultural Performance in Nigeria. South Asian Res J Bus Manag, 3(1), 1-13. 